\title{
KEDUDUKAN AHLI WARIS PENGGANTI (PLAATSVERVULLING) DALAM KOMPILASI HUKUM ISLAM DAN PEMECAHANNYA
}

\author{
Abdul Qodir Zaelani \\ Universitas Islam Negeri Raden Intan Lampung \\ Email: abdulqodirzaelani@radenintan.ac.id \\ DOI: 10.37876/adhki.v2i1.32
}

\begin{abstract}
This Aritkel seeks to analyze the renewal of Islamic Family Law in Indonesia through the analysis of existing laws in Indonesia. The result is a unique breakthrough contained in $\mathrm{KHI}$ is a real thing that legislation in Indonesia is very concerned that in the close relationship between Islamic law and adat. Islamic inheritance law, especially substitute heirs in the laws of Compilation of Islamic Law (KHI) in Indonesia is unique. Based on juridical analysis, it was found that the existence of substitute heirs was an eclectic meeting of Islamic law and local wisdom. So, in resolving the problem of heirs can use KHI, local wisdom, judge's decision (jurisprudence).
\end{abstract}

Keywords: Inheritance law, heirs, customary law

\section{Abstrak}

Aritkel ini berusaha menganalisa pembaruan Hukum Keluarga Islam di Indonesia melalui analisis perundang-undangan yang berlaku di Indonesia saat ini. Hasilnya adalah terobasan unik yang termaktub dalam KHI merupakan hal yang nyata perundang-undangan di Indonesia sangat memperhatikan bahwa di hubungan erat antara hukum Islam dengan adat. Hukum waris Islam, terkhusus ahli waris pengganti dalam perundang-undangan Kompiltasi Hukum Islam (KHI) di Indonesia merupakan hal unik. Berdasarkan analisis yuridis, ditemukan eksistensi ahli waris pengganti merupakan pertemuan ekletisisme hukum Islam dan local wisdom. Maka dalam menyelesaikan persoalan ahli waris bisa memakai KHI, local wisdom, putusan hakim (jurisprudensi).

Kata Kunci: Hukum waris, ahli waris, hukum adat

\section{Pendahuluan}

Hukum kewarisan merupakan bagian dari hukum kekeluargaan yang memegang peranan penting, bahkan menentukan dan mencerminkan sistem kekeluargaan yang berlaku dalam masyarakat. Hukum kewarisan bila ditinjau dalam kacamata antropologis, sangat erat hubungannya dengan sistem kekerabatan yang terdapat pada masyarakat Indonesia, hal ini di sebabkan keberagaman akan agama dan kebudayaan yang berbeda-beda. Secara teoritis sistem kekerabatan terbagi 3 
sistem, ${ }^{1}$ yakni sistem patrilineal, ${ }^{2}$ sistem matrilineal, ${ }^{3}$ dan sistem parental atau bilateral. ${ }^{4}$

Bila ditinjau dalam perspektif ekonomi, menerima warisan tidak selalu mendapatkan keuntungan, ada kalanya warisan itu hanya berisi utang-utang yang ditinggalkan saja. Dengan demikian seorang waris atau ahli waris dapat membuat pilihan terhadap warisan. Apabila ahli waris menerima warisan, maka penerimaan itu ada 2 (dua) macam yaitu: ${ }^{5}$ penerimaan secara penuh, ${ }^{6}$ dan menerima secara benificiar (menerima dengan syarat). ${ }^{7}$ Konsekuensi dari keduanya yakni apabila penerimaan warisan secara penuh mengakibatkan warisan tersebut menjadi satu dengan harta kekayaan ahli waris yang menerima itu. Dan ahli waris berkewajiban melunasi hutang-hutang si pewaris. Dengan kata lain, para kreditur pewaris dapat menuntut pembayaran dari ahli waris itu. Namun jika harta kekayaan pewaris itu tidak mencukupi, maka ahli waris harus membayar kekurangannya dengan harta kekayaannnya sendiri. Sementara menerima warisan secara benefisier memberikan konsekuensi: ${ }^{8}$

1. Seluruh warisan terpisah dari harta kekayaan pribadi ahli waris.

2. Ahli waris tidak perlu menanggung pembayaran utang-utang pewaris dengan kekayaannya sendiri sebab pelunasan utang-utang pewaris berdasarkan kekuatan harta warisan yang ada.

3. Tidak terjadi percampuran harta kekayaan antara harta pribadi dan harta peninggalan.

4. Bila masih ada sisa harta peninggalan, maka sisa itulah yang menjadi bagian ahli waris.

Bila ditinjau dalam kacamata normative, permasalahan kewarisan, terutama masalahan ahli waris pengganti menjadi perbincangan yang menarik. Hal ini terbukti dalam Rapat Kerja Nasional Mahkamah Agung 2009 di Palembang ada sesi khusus yang membahas masalah ini. Salah satu perdebatan yang selama ini muncul, apakah penentuan ahli waris pengganti bersifat wajib atau tentatif. Sebab, dalam Kompilasi Hukum Islam (KHI) yang merupakan kesepakatan para Ulama dan Perguruan Tinggi berdasarkan Inpres No. 1/1991 yang isinya berupa perintah kepada Menteri Agama

${ }^{1}$ Hilman Hadikusuma, Hukum Waris Adat, (Bandung: PT. Citra Aditya Bakti, 1990), h. 23

2 Yaitu sistem keturunan yang ditarik menurut garis bapak, di mana kedudukan pria lebih mendominasi dalam hal kewarisan.

3 Yaitu sistem keturunan yang ditarik menurut garis ibu, di mana kedudukan wanita lebih mendominasi dalam hal kewarisan.

4 Yaitu sistem keturunan yang ditarik menurut garis orang tua atau menurut garis dua sisi (bapak-ibu), di mana kedudukan pria dan wanita tidak dibedakan dalam pewarisan.

5 Subekti, Ringkasan Tentang Hukum Keluarga dan Hukum Waris, Jakarta: Intermasa, 1990, h. 22

${ }^{6}$ Penerimaan dengan penuh dapat dilakukan dengan tegas atau dilakukan dengan cara diamdiam. Dengan tegas apabila seseorang dengan suatu akta menerima kedudukannya sebagai ahli warisnya. Dan dengan diam-diam apabila melakukan perbuatan yang dengan jelas menunjukan maksudnya menerima warisan, misalnya melunasi hutang-hutang pewaris, mengambil atau menjual barang warisan.

7 Ahli waris menyatakan menerima secara beneficiar artinya ahli waris bersedia menerima warisan dengan syarat terbatas untuk membayar kewajiban atau beban utang berdasarkan kemampuan dari harta warisan itu sendiri, tanpa harus bercampur dengan harta pribadinya.

${ }^{8}$ A. Pitlo, Hukum Waris. Menurut Kitab Undang-Undang Hukum Perdata Belanda, Jilid 2 , Jakarta: PT Intermasa, 1991, h. 142. 
untuk menyebarluaskan KHI, bukan instruksi supaya dijadikan sebagai hukum terapan bagi Pengadilan Agama. Setelah 20 tahun KHI diterapkan sebagai hukum materiil bagi Pengadilan Agama, muncullah Buku II Tentang Hukum Kewarisan terutama pasal Pasal $185 \mathrm{KHI}$ tentang ahli waris pengganti yang didalamnya banyak terdapat pemikiran-pemikiran Hazairin.

Di dalamnya beberapa peserta menggugat pemikiran ahli waris pengganti yang selalu dinisbatkan kepada Hazairin, sebagai penggagas teori kewarisan bilateral yang kemudian diadopsi dalam sistem hukum Islam Indonesia. Perdebatan ini muncul karena memang ketentuan ahli waris pengganti memang tidak diatur dalam fikih, sama halnya dengan beberapa ketentuan lainnya seperti wasiat wajibah. ${ }^{9}$ Sebab itulah, tulisan ini mencoba mengungkap bagaimanakah sebenarnya permasalahan ahli waris pengganti tersebut? Atas dasar apakah konsep ahli waris pengganti merupakan bagian "keunikan" tersendiri yang disusun dalam Kompilasi Hukum Islam?

\section{Ahli Waris Pengganti dalam Perspektif Yuridis}

Sebelum menjelaskan ahli waris pengganti dalam perspektif yuridis, alangkah baiknya melihat terlebih dahulu prinsip pewarisan Islam ditinjau dalam kacamata historis-substantif, yang pernah menjadi suatu perbincangan menarik dalam simposium hukum waris nasional tahun 1983 di Jakarta, sebagai berikut:10

1. Hukum waris Islam tidak memberikan kebebasan penuh kepada seseorang untuk pengosongkan harta peninggalannya dengan jalan wasiat pada orang yang disayanginya. Sebaliknya juga tidak melarang sama sekali pembagian hartanya semasa ia masih hidup.

2. Oleh karena pewarisan merupakan aturan hukum maka pewaris tidak boleh meniadakan hak ahli waris atas harta warisan. Sebaliknya ahli warispun berhak atas harta peninggalan tanpa syarat pernyataan secara sukarela atau melalui Putusan Pengadilan (hakim).

3. Pewarisan terbatas di lingkungan kerabat baik berdasarkan hubungan perkawinan maupun ikatan keturunan yang sah.

4. Hukum waris Islam cenderung membagikan harta warisan kepada ahli waris dalam jumlah yang berhak diterimanya untuk dimiliki secara perorangan menurut kadar bagian masing-masing, baik harta yang ditinggalkan itu sedikit atau banyak jumlahnya.

5. Perbedaan umur tidak membawa pembedaan dalam hak mewarisi bagi anakanak. Perbedaan besar kecilnya bagian warisan berdasarkan berat ringannya kewajiban dan tanggung jawab anak dalam kehidupan kerabat.

Sementara dalam hal corak dan karakteristik, bahwa hukum kewarisan Islam mempunyai corak atau karakteristik tersendiri, yang berbeda dengan hukum kewarisan yang lain, corak atau karakteristik tersebut adalah :

1. Perolehan perseorangan ahli waris

9 Amir Syarifuddin, Pelaksanaan Hukum Kewarisan Islam Dalam Lingkungan Adat Minangkabau Jakarta: Gunung Agung, 1984, h. 86

${ }^{10}$ Imam Sudiyat, Peta Hukum Waris di Indonesia, Jakarta: Simposium Hukum Waris Nasional, 1983, h. 9-10 
Maksudnya perolehan yang diperuntukan bagi perseorangan yaitu bagian tertentu bagi orang-orang tertentu, dalam keadaan tertentu. Angka-angka faraid $1 / 8,1 / 4,1 / 6,1 / 3,1 / 2$, dan $2 / 3$ menunjukan jaminan kepemilikan secara individu. Untuk anak laki-laki memperoleh bagian dua kali anak perempuan.

2. Variasi pengurangan perolehan ahli waris

Variasi pengurangan perolehan terjadi karena adanya orang-orang tertentu dalam keadaan tertentu memperoleh bagian yang tertentu atau kehadiran dzawul faraid lainnya. Contohnya dapat dilihat dalam beberapa garis hukum :

a. Garis hukum Surat An-Nisa' ayat 11, perolehan dzawul faraid dua orang anak perempuan atau lebih 2/3, satu orang anak perempuan 1/2.

b. Garis hukum Surat An-Nisa' ayat 12, perolehan untuk duda atau janda, dari $1 / 2$ menjadi $1 / 4$ untuk duda karena ada anak, dari $1 / 4$ menjadi $1 / 8$ untuk janda karena ada anak. Pengurangan perolehan bagian warisan disebabkan oleh jumlah mereka berbeda.

c. Garis hukum Surat An-Nisa' ayat 176, perolehan bagi satu saudara perempuan $1 / 2$, dua orang saudara perempuan atau lebih $2 / 3 .^{11}$

3. Metode penyelesaian pembagian warisan

Adanya metode penyelesaian yang dikenal dengan Aul dan Rad. Aul adalah suatu cara penyelesaian bila terjadi ketekoran dalam pembagian harta warisan, dilakukan pengurangan terhadap bagian masing-masing ahli waris secara berimbang. Rad adalah pengembalian sisa harta setelah dibagi kepada dzawul faraid, sisa harta tersebut dibagi secara berimbang oleh ahli waris dzawul faraid. ${ }^{12}$

\section{Ahli Waris Pengganti dalam Perspektif KUH Perdata}

Ahli waris pengganti dalam hukum waris Perdata dikenal dengan istilah Penggantian tempat yang dalam bahasa Belanda Plaatsvervulling. Hal ini diatur dalam Pasal 854 s/d 857 dihubungkan dengan Pasal 860 dan Pasal 866. Penggantian memberi hak kepada orang yang menggantikan untuk bertindak sebagai pengganti dalam derajat dan dalam segala hak orang yang digantikannya sebagaimana diatur dalam Pasal $841 \mathrm{KUH}$ Perdata umpamanya: seorang cucu yang menggantikan orang tuanya yang sudah meninggal lebih dahulu selaku anak dari pewaris, berhak atas semua hak itu. Penggantian dalam garis lurus ke bawah yang sah, berlangsung terus tanpa batas (Pasal 842 ayat 1). Dalam segala hal, penggantian seperti di atas selamanya diperbolehkan, baik dalam hal beberapa orang anak pewaris, mewarisi bersama-sama satu sama lain dalam pertalian keluarga yang berbeda-beda derajatnya (Pasal 842 ayat 2).

Dalam garis menyimpang, penggantian diperbolehkan atas keuntungan anakanak dan keturunan saudara laki-laki dan perempuan yang telah meninggal lebih dahulu, baik mereka mewarisi bersama-sama dengan paman atau bibi mereka, maupun bersama-sama dengan keturunan paman atau bibi itu, meskipun mereka dalam derajat yang tidak sama (Pasal 844). Bila disamping ayah atau ibu yang masih

\footnotetext{
11 Zainuddin Ali, Pelaksanaan Hukum Waris di Indonesia, Jakarta: Sinar Grafika, 2008, h. 23

${ }^{12}$ Hazairin, Hukum Kewarisan Bilateral menurut Qur'an dan Hadith, Jakarta: Tintamas, 1964, h. 45
} 
hidup itu hanya ada seorang saudara, maka ayah atau ibu itu menerima $1 / 2$ dan $1 / 2$ lagi untuk saudara atau keturunannya. ${ }^{13}$

Jadi dengan penggantian tempat (plaatvervulling), maka keturunan dari seseorang masuk dalam hubungan hukum yang sama seperti orang yang digantinya, seandainya orang yang diganti masih hidup. Lalu undang-undang mengatakan bahwa dia yang menggantikan tempat akan memperoleh hak-hak (dan juga kewajiban) dari orang yang digantikannya, jika sekiranya ia tidak meninggal sebelum pewaris meninggal dunia. ${ }^{14}$

Setelah masalah ahli waris Pengganti ini masuk dalam KHI yang dirumuskan dalam pasal 185, ternyata dalam pelaksanaannya berkembang jauh dari aslinya, bahkan mengacu pada BW, di mana terdapat tiga macam bentuk ahli waris pengganti, sebagai berikut:

1. Penggantian dalam garis lencang ke bawah, yaitu penggantian seseorang oleh keturunannya, dengan tidak ada batasnya, selama keturunannya itu tidak dinyatakan onwaarding atau menolak menerima warisan (Pasal 842). Dalam segala hal, pergantian seperti di atas selamanya diperbolehkan, baik dalam hal bilamana beberapa anak yang meninggal mewaris bersama-sama, satu sama lain dalam pertalian keluarga yang berbeda-beda derajatnya.

2. Penggantian dalam garis kesamping (zijlinie), di mana tiap-tiap saudara yamh meninggal dunia, baik sekandung maupun saudara tiri, jika meninggal dunia lebih dahulu, digantikan oleh anak-anaknya. Juga penggantian ini dilakukan dengan tiadabatasnya (Pasal 853, jo. Pasal 856, jo. Pasal 857)

3. Penggantian dalam garis ke samping menyimpang dalam hal kakek dan nenek baik dari pihak ayah maupun dari pihak ibu, maka harta peninggalan diwarisi oleh golongan keempat, yaitu paman sebelah ayah dan sebelah ibu. Pewarisan ini juga dapat digantikan oleh keturunannya sampai derajat keenam (Pasal 861).

\section{Ahli Waris Pengganti dalam Perspektif KHI}

KHI yang merupakan kumpulan materi/bahan hukum Islam yang tersebar di perbagai kitab fikih klasik, di samping bahan-bahan lain yang berhubungan, kemudian diolah melalui proses dan metode tertentu, lalu dirumuskan dalam bentuk yang serupa perundang-undangan (yaitu dalam pasal-pasal tertentu) lahir berdasarkan atas landasan Instruksi Presiden Nomor 1 Tahun 1991 tertanggal 10 Juni 1991,15 yang

13 Ismuha, Penggantian Tempat Dalam Hukum Waris Menurut K.U.H.Perdata, Hukum Adat dan Hukum Islam, Jakarta: Bulan Bintang, 1978,h. 73

14 Suparman Usman, Ikhtisar Hukum Waris Menurut Kitab Undang-Undang Hukum Perdata (Burgerlijk Wetboek), Serang: Darul Ulum Press, 1993, h. 87

${ }^{15}$ Abdurrahman, Paradigma Baru tentang Kewenangan Peradilan Agama di Indonesia, hal.7. Makalah disampaikan pada seminar dalam rangka Rapat Kerja Para Dekan Fakultas Syariah seluruh Indonesia di Banjarmasin tanggal 19 September 2006 hal. 14 dan lihat Farid Mu'adz dalam pengaruh ajaran "Tsulutsul Baaqi" dalam Kompilasi Hukum Islam, Panji Masyarakat, Nomor 806, 16 Jumadil Awwal 1415 H, 11-21 Oktober 1994. KHI ini terdiri dari tiga buku, buku I tentang hukum perkawinan, buku II tentang hukum kewarisan, dan buku III tentang hukum perwakafan 
merupakan positifisasi hukum Islam di Indonesia,16 yang bertujuan untuk melaksanakan peraturan perundang-undangan yang berlaku. ${ }^{17}$ Kompilasi Hukum Islam memiliki konsistensi dengan peraturan perundang-undangan yang kedudukannya lebih tinggi dan dijadikan rujukan sebagaimana telah disebutkan. ${ }^{18}$ Sementara kedudukan Kompilasi Hukum Islam dalam sistem hukum nasional, diukur oleh unsur-unsur sistem hukum nasional. ${ }^{19}$

Kompilasi Hukum Islam dalam Buku II tentang kewarisan Pasal 185 ayat (1) mengatur bahwa ahli waris yang meninggal terlebih dahulu dari pewaris, maka kedudukannya dapat digantikan oleh anaknya, kecuali mereka yang tidak dapat jadi ahli waris karena dihukum berdasarkan Putusan Pengadilan yang telah mempunyai kekuatan hukum tetap sebagimana tersebut dalam Pasal 173 Kompilasi Hukum Islam.

Salah satu konsep pembaharuan Hukum Kewarisan Islam Indonesia dalam Kompilasi Hukum Islam (KHI) adalah diberikannya hak seorang ahli waris yang telah meninggal dunia kepada keturunannya yang masih hidup. Seiring dengan perkembangannya azas persamaan hak dan kedudukan yang diatur dalam pasal 185 KHI: "Ahli Waris yang meninggal dunia lebih dahulu dari si pewaris maka kedudukannya dapat digantikan oleh anaknya". Aturan ini tercantum dalam Pasal 185 KHI yang bunyi lengkapnya adalah sebagai berikut:

1. Ahli waris yang meninggal dunia lebih dahulu dari pada pewaris, maka kedudukannya dapat digantikan oleh anaknya, kecuali mereka yang tersebut dalam Pasal 173.

2. Bagian ahli waris pengganti tidak boleh melebihi dari bagian ahli waris yang sederajat dengan yang diganti.

Mengganti kedudukan orang tua yang meninggal dunia tersebut selanjutnya disebut ahli waris pengganti. Ketentuan semacam ini tidak dijumpai dalam fikih

${ }^{16}$ Lihat Zarkowi Soejoeti, "Sejarah Penyusunan Kompilasi Hukum Islam di Indonesia", dalam Dadan Muttaqien, dkk., Peradilan Agama dan Kompilasi Hukum Islam dalam Tata Hukum Indonesia, edisi II Yogyakarta: UII Press, 1999, h. 53-54.

17 A. Hamid S. Attamimi, "Kedudukan Kompilasi Hukum Islam dalam Sistem Hukum Nasional” dalam Amrullah Ahmad dkk., Dimensi Hukum Islam dalam Sistem Hukum Nasional, cet. ke-1; Jakarta: Gema Insani Press, 1996, h. 152.

18 Peraturan Perundang-undangan di atas Inpres adalah Keputusan Presiden, Peraturan Pemerintah, dan Undang-undang. Selanjutnya lihat TAP MPRS Nomor XX/MPRS/1966.

19 Ada empat alasan dalam hal ini, Pertama, landasan ideal dan konstitusional Kompilasi Hukum Islam adalah Pancasila dan Undang-Undang Dasar 1945. Hal itu dimuat dalam konsideran Instruksi Presiden dan dalam Penjelasan Umum Kompilasi Hukum Islam. Ia disusun sebagai bagian dari sistem hukum nasional yang menjamin kelangsungan hidup beragama berdasarkan Ketuhanan Yang Maha Esa yang sekaligus merupakan perwujudan kesadaran hukum masyarakat dan bangsa Indonesia; kedua, Kompilasi Hukum Islam dilegalisasi oleh instrumen hukum dalam bentuk Instruksi Presiden yang dilaksanakan oleh Keputusan Menteri Agama yang merupakan bagian dari rangkaian peraturan perundang-undangan yang berlaku; ketiga, Kompilasi Hukum Islam dirumuskan dari tatanan hukum Islam yang bersumber dari Alquran dan hadis Nabi saw. Hal itu menjadi inti hukum Islam yang mencakup berbagai dimensi syariat, fikih, fatwa, dan adat. Kompilasi Hukum Islam merupakan perwujudan hukum Islam yang bercorak ke-Indonesiaan; dan keempat, saluran dalam aktualisasi Kompilasi Hukum Islam antara lain pengadilan dalam lingkungan Peradilan Agama, sebagaimana dapat ditafsirkan secara teologis dari penjelasan umum Kompilasi Hukum Islam. lihat Andi Herawati, Kompilasi Hukum Islam (KHI) Sebagai Hasil Ijtihad Ulama Indonesia, Jurnal Studia Islamika, Vol. 8, No.2, Desember 2011 h 332-333 
empat mazhab, akan tetapi merupakan adopsi dari hukum waris Islam Pakistan, di mana ahli waris pengganti itu hanyalah cucu saja.

Konsep tersebut merupakan sumbangsih dalam upaya pembaharuan hukum Islam khususnya masalah ahli waris pengganti, seseorang yang meninggal dunia terlebih dahulu di gantikan oleh keturunannya dalam hal ini anak untuk menerima warisan dari kakeknya. Pencantuman ahli waris pengganti dalam kompilasi hokum Islam dengan tujuan untuk memenuhi rasa keadilan hukum.

\section{Ahli Waris Pengganti: Catatan Epistemologi}

Ahli waris pengganti dalam hukum kewarisan Islam untuk melengkapi hukum-hukum yang telah ada dan juga bertujuan untuk mencari rasa keadilan bagi ahli waris. Waris pengganti pada dasarnya adalah ahli waris karena penggantian yaitu orang-orang yang menjadi ahli waris karena orang tuanya yang berhak mendapat warisan meninggal lebih dahulu dari pewaris, sehingga dia tampil menggantikannya. ${ }^{20}$

Namun satu hal yang patut digarisbawahi, kehadiran Kompilasi Hukum Islam ini sudah merupakan satu terobosan baru dalam hubungannya dengan serangkaian reformasi hukum di bidang ahwal syakhshiyyah, termasuk masalah kewarisan. Dengan pengertian lain, pada sebagian pasal-pasalnya, sudah terkandung aspek-aspek reformatif hasil sumbangan pemikiran sejumlah tokoh dan pemerhati hukum, yang mereka upayakan dan suarakan diperbagai kesempatan, dalam waktu dan perjuangan yang relatif panjang.

Dalam Kompilasi Hukum Islam berdasarkan Inpres No. 1 tahun 1991, ketentuan ahli waris pengganti dimuat dalam Pasal 185. Hazairin menyimpulkan adanya sistem penggantian dalam hokum kewarisan Islam berdasarkan pada Firman Allah dalam surat An-Nisa ayat 33 dengan istilah Mawali, yaitu ahli waris karena penggantian, yaitu orang-orang yang menjadi ahli waris karena tidak ada lagi penghubung antara mereka dengan pewaris.

Para mujtahid terdahulu pada umumnya berpendapat bahwa kelompok yang disebut sebagai ahli waris pengganti itu, hak yang mereka terima bukanlah hak yang seharusnya diterima oleh ahli waris yang digantikannya. Para mujtahid terdahulu tetap menempatkannya sebagai cucu, bukan sebagai pengganti ayahnya. Cucu yang dimaksud di sini khusus cucu melalui anak laki-laki. Dengan kata lain, cucu yang ayahnya sudah terlebih dahulu meninggal dunia, tidak berhak menerima warisan kakeknya bila saudara laki-laki dari ayahnya itu ada yang masih hidup. ${ }^{21}$

Mengenai ahli waris pengganti dalam konteks ke-Indonesia-an, tidak dapat dilepaskan dari pemikiran Hazairin, yang menyimpullkan bahwa hukum kewarisan Islam bercorak bilateral dan mengenal ahli waris pengganti. Dasar Islam menganut sistem kewarisan Bilateral, didasarkan dari penafsiran Al-Qur'an surat An-Nisa ayat $11{ }^{22}$ dalam ayat tersebut menunjukkan bahwa anak laki-laki dan anak perempuan

\footnotetext{
${ }^{20}$ Ahmad Zahari, Hukum Kewarisan Islam, Pontianak: FH.Untan Pres, 2008, h. 148

21 Amir Syarifuddin, 1984, Pelaksanaan Hukum Kewarisan Islam dalam Lingkungan Adat Minangkabau, Jakarta: Gunung Agung, h. 86-87

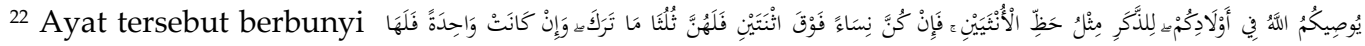

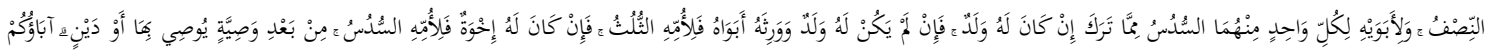

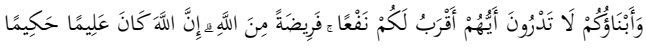


mewaris dari ibu bapaknya. Ayah dan ibu mewaris dari anaknya laki-laki maupun anak perempuan. Ini menunjukkan bahwa hak mewaris bagi orang laki-laki dan orang perempuan sama, artinya baik laki-laki ataupun perempuan mewaris tanpa melihat apakah yang diwarisi itu laki-laki atau perempuan, apalagi kalau ayat ini dikaitkan dengan surat An-Nisa ayat 7,23 menunjukkan bahwa Al-Qur'an menghendaki sistem bilateral dalam bidang kewarisan. Jika mengenai persoalan cucu, maka konsistensi dengan ayat tersebut sangat penting, karena menurut Hazairin sistem kewarisan bilateral mempunyai konsekwensi untuk adanya sistem penggantian tempat ahli waris dalam hukum kewarisan Islam.

Sementara kesimpulan beliau tentang ahli waris pengganti itu didasarkan pada penafsiran Al-Qur' an surat An-Nisa ayat 33, yang berbunyi sebagai berikut:

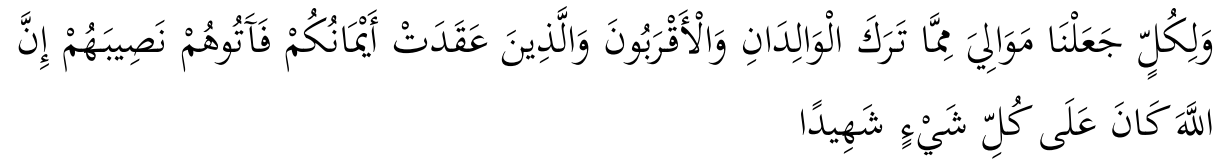

"Bagi tiap-tiap harta peninggalan dari harta yang ditinggalkan ibu bapak dan karib kerabat, Kami jadikan pewaris-pewarisnya. Dan (jika ada) orangorang yang kamu telah bersumpah setia dengan mereka maka berilah kepada mereka bahagiannya. Sesungguhnya Allah menyaksikan segala sesuatu ".

Oleh Hazairin, mawali tersebut ditafsirkan sebagai ahli waris. ${ }^{24}$ Penggantian tempat ahli waris ditafsirkan dari ayat Al-Qur'an surat An-Nisa ayat 33 yang dikatakan sebagai ayat yang mendasari adanya ahli waris pengganti. Senada dengan Hazairin, Sajuti Thalib menafsirkan firman Allah dalam surat An-Nisa ayat 33, yang diuraikan dalam beberapa garis hukum, sebagai berikut:25

1. Dan bagi setiap orang kami (Allah) telah menjadikan mawali (ahli waris pengganti) dari (untuk mewarisi) harta peninggalan ibu bapaknya (yang tadinya akan mewarisi harta peninggalan itu).

2. Dan bagi setiap orang kami (Allah) telah menjadikan mawali (ahli waris pengganti) dari (untuk mewarisi) harta peninggalan aqrabunnya (yang tadinya akan mewarisi harta peninggalan itu).

3. Dan bagi setiap orang kami (Allah) telah menjadikan mawali (ahli waris pengganti) dari (untuk mewarisi ) harta peninggalan tolan seperjanjiannya (yang tadinya akan mewarisi harta peninggalan itu).

4. Maka berikanlah kepada mereka warisan mereka.

Sajuti Thalib mengemukakan pendapat bahwa ahli waris pengganti itu diambil dari pengertian mawali, maksudnya ahli waris yang menggantikan seseorang untuk memperoleh bagian warisan yang tadinya akan diperoleh orang yang digantikan itu. Mereka yang menjadi mawali ini ialah keturunan anak pewaris, keturunan saudara pewaris atau keturunan orang yang mengadakan semacam perjanjian mewaris (bentuknya dapat saja dalam bentu wasiat) dengan pewaris. Dengan demikian menurut ajaran bilateral Hazairin yang dianut oleh Sajuti Thalib beserta muridmuridnya dikenal adanya lembaga bij plaatsvervulling atau penggantian ahli waris.

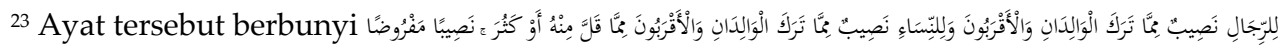

${ }^{24}$ Hazairin, Hukum Kewarisan Bilateral menurut Qur'an dan Hadith, Jakarta: Tintamas, 1964, h. 8

${ }^{25}$ Sajuti Thalib, Hukum Kewarisan Islam di Indonesi, Jakarta: Bina Aksara, 1982, h. 27
} 
Masih dalam pandangan Hazairin, ahli waris menurut Al-Qur'an oleh Hazairin dibedakan menjadi tiga kelompok yaitu dzawu al-faraid, dzawu al-qarabat dan Mawali. Dalam Al-Qur'an surat An-Nisa ayat 33 tersebut pula, Hazairin menerjemahkan nasibahum sebagai bagian kewarisan yaitu sesuatu bagian dari harta peninggalan. Ayat ini menjelaskan bahwa nasib itu diberikan kepada mawali. ${ }^{26}$

Selain itu, untuk membuktikan bahwa hukum kewarisan Islam mengenal ahli waris pengganti, beliau menguraikan juga bahwa hukum kewarisan Islam bercorak bilateral. Dalam sistem kewarisan bilateral hak mewaris laki-laki sama dengan hak mewaris perempuan, artinya baik laki-laki maupun perempuan sama-sama berhak mewaris. Kalau hak laki-laki dalam mewaris sama dengan hak perempuan, maka tidak dipersoalkan lagi. Menurutnya, tidak ada satu indikator (petunjuk) pun yang membuktikan bahwa cucu dari garis perempuan tidak dapat mewaris. ${ }^{27}$

Dalam mengemukakan pikirannya, Hazairin berbeda pendapat dengan pendapat mujtahid terdahulu bahwa cucu yang ayahnya lebih dahulu meninggal menempati kedudukan ayahnya dalam mendapati harta warisan kakeknya. Menurut Hazairin kedudukan al-walidani adalah subjek dari kata kerja taraka. Oleh karena itu maka pengertian mawaaliya adalah cucu dari anak yang sudah meninggal lebih dahulu, terhalang dengan adanya anak laki-laki lain yang masih hidup. Cara pewarisan seperti ini disebut pewarisan secara penggantian yang dalam BW disebut pewarisan secara plaatsvervulling.

Untuk memperdalam pemikiran Hazairin, bisa dijelaskan bahwa pewaris adalah ayah atau ibu atau aqrabun. Jika ayah atau ibu yang mati maka yang mewarisi dan seandainya anak atau salah seorang dari anaknya mati lebih dahulu dari pewaris (ayah atau ibu) maka diberikan kepada cucu sebagai mawali dari anak yang mati tadi, maksudnya mawali anak tersebut ikut serta sebagai ahli waris terhadap harta pewaris (orang tua). Hubungan kewarisan yang menyebabkan cucu menjadi ahli waris atas dasar pertalian darah antara pewaris dengan anggota keluarga yang masih hidup. Maka hubungan anak dengan mawalinya (cucu) adalah hubungan pewaris dengan keturunannya melalui mendiang anaknya yang sudah mati. Mawali disebut juga ahli waris karena penggantian, jadi yang dimaksud dengan mawali adalah orang-orang yang yang menjadi ahli waris karena tidak ada lagi penghubung antara mereka dengan pewaris, disebabkan karena orang yang menjadi penghubung tersebut telah mati lebih dahulu dari pewaris, yang mana ia seharusnya menerima warisan kalau ia masih hidup.

Jika seorang meninggal dunia, ahli waris terdiri dari anak, cucu, saudara, ayah, ibu dan kakek serta nenek. Dari sekian banyak ahli waris diadakan penentuan siapasiapa yang berhak memperoleh bagian warisan. Apabila antara pewaris dengan ahli waris tidak ada penghubung, maka dapat dikatakan mewaris secara langsung, seperti anak mewaris dari orang tuanya. Tetapi apabila antara pewaris dengan ahli waris tidak ada lagi penghubung yang masih hidup, dapat dikatakan ahli waris tersebut

${ }^{26}$ Hazairin, Hukum Kewarisan Bilateral Menurut Qur'an dan Hadith, Jakarta: Tintamas Indonesia, 1964, h. 29

27 A. Rachmad Budiono, Pembaharuan Hukum Kewarisan Islam di Indonesia, Bandung : PT.Citra Aditya Bakti, 1999, h. 32 
mewaris karena penggantian, misalnya seorang cucu yang orang tuanya meninggal lebih dahulu dari pewaris.

Untuk menentukan siapa-siapa yang menjadi ahli waris dari keseluruhan ahli waris yang ada, inilah yang disebut oleh Hazairin dengan garis pokok penggantian. Jadi, garis pokok penggantian adalah setiap orang dalam sekelompok keutamaan, dengan syarat bahwa antara dia dengan pewaris tidak ada penghubung atau tidak ada lagi penghubung yang masih hidup. Hazairin membagi empat kelompok keutamaan, yaitu: ${ }^{28}$

1. Keutamaan pertama

a. Anak-anak, laki-laki dan perempuan, atau sebagai dzawu al-faraid atau sebagai dzawu al-qarabat beserta mawali bagi mendiang-mendiang anak laki-laki dan perempuan.

b. Orang tua (ayah dan ibu) sebagai dzawu al-faraid.

c. Janda atau duda sebagai dzawu al-faraid

2. Keutamaan kedua

a. Saudara, laki-laki dan perempuan atau sebagai dzawu alfaraid atau sebagai $d z a w u$ al-qarabat, beserta mawali bagi mendiang-mendiang saudara laki-laki dan perempuan dalam hal kalalah.

b. Ibu sebagai dzawu al-faraid.

c. Ayah sebagai dzawu al-qarabat dalam hal kalalah.

3. Keutamaan ketiga

a. Ibu sebagai dzawu al-faraid.

b. Ayah sebagai dzawu al-qarabat.

c. Janda atau duda sebagai dzawu al-faraid

4. Keutaman keempat

a. Janda atau duda sebagai dzawu al-faraid

b. Mawali untuk ibu.

c. Mawali untuk ayah.

Setiap kelompok keutamaan dirumuskan dengan penuh yang artinya kelompok keutamaan yang lebih rendah tidak mewaris bersama-sama dengan kelompok keutamaan yang lebih tinggi karena kelompok keutamaan yang lebih rendah tertutup oleh kelompok keutamaan yang lebih tinggi.

Persisnya mawali itu bagi seseorang adalah:

1. Meletakkan ikatan kewarisan antara orang-orang yang sepertalian darah dengan pengecualian hubungan antara suami dan isteri.

2. Adanya hubungan kekeluargaan antara yang diadakan dengan pihak asal keturunannya dan sebaliknya. Hubungan seseorang yang telah mati dengan mawalinya mungkin hubungan kedarahan ke garis bawah atau ke garis sisi atau ke garis atas. ${ }^{29}$

\section{Pemecahan Ahli Waris Pengganti} 1964 , h. 37

${ }^{28}$ Hazairin, Hukum Kewarisan Bilateral Menurut Qur'an dan Hadith, Jakarta: Tintamas Indonesia, ${ }^{29}$ Ibid., h. 31 
Harus diakui bahwa ahli Waris Pengganti menurut Kompilasi Hukum Islam terdapat berbagai polemik dalam hukum kewarisan Islam, terutama masalah penentuan dan bagian yang diterima oleh seorang ahli waris yang tidak diatur secara tegas atau pengaturannya secara garis besarnya dalam Al-Qur'an dan tidak ada penjelasan dari as sunnah.

Suatu terobasan yang dilakukan di Indonesia dengan tetap mendasari kepada Al-Qur'an dan Sunnah serta Ijtihad para ulama fiqih terdahulu, untuk dijadikan sebagai pedoman dan acuan dalam menyelesaikan suatu masalah kewarisan disusunlah suatu buku Kompilasi Hukum Islam yang berlaku dengan Instruksi Presiden Republik Indonesia Nomor 1 tahun 1991 tanggal 10 Juni 1991, dan Surat Keputusan Menteri Agama Republik Indonesia No. 154 tahun 1991 tentang Pelaksanaan Instruksi Presiden Republik Indonesia No. 1 tahun 1991, tanggal 22 Juli 1991. Sebeb, bila ditilik dalam sejarah, sebelumnya dalam penyelesaian masalah kewarisan di Indonesia memakai hukum kewarisan dalam mazhab Syafe'i dengan sistem patrilinialnya sesuai dengan Surat Edaran Biro Peradilan Agama Departemen Agama RI Nomor : B/1/735 tanggal 18 Februari 1958.

Dalam KHI pengaturan tentang ahli waris dan bagian ahli waris dimuat dalam buku II secara jelas dan yang merupakan ketentuan yang diatur dan berlakunya ahli waris pengganti dalam pembagian warisan, yang selama ini tidak dikenal dalam mazhab Syafe'i.

Ahli waris pengganti pada dasarnya ahli waris karena penggantian, dapat diartikan sebagai orang-orang yang menjadi ahli waris karena orang tuanya yang berhak mendapat warisan meninggal lebih dahulu dari pada pewaris, sehingga kedudukannya digantikan olehnya. Jika kita cermati bunyi Pasal 185 ayat 1 dan 2 mengandung pengertian yang luas, yang sebelumnya para ahli fiqih berbeda pendapat tentang kedudukan, jenis kelamin, hak yang diperoleh dan batasan bagian perolehan bagi mereka yang menjadi ahli waris pengganti.

Dalam pasal tersebut semua perbedaan pendapat seperti di atas diakomodir menjadi satu pasal yang mengandung pengertian ahli waris pengganti dalam arti yang luas. Sistem kewarisan bilateral Hazairin dengan mawalinya pada prinsipnya sama dengan ahli waris pengganti KHI dengan tidak meninggalkan sistem kewarisan patrilinial Syafe'i yang tidak mengenal adanya ahli waris pengganti dengan acuan dan dasar utama Al-Qur'an.

Jadi, dengan ada dan berlakunya Kompilasi Hukum Islam sebagai acuan dalam menyelesaikan masalah kewarisan di Indonesia khususnya dalam hal adanya/tampilnya ahli waris pengganti sebagai yang mewaris bersama-sama dengan ahli waris lainnya.

\section{Mengakomodir Kearifan Lokal (Local Wisdom)}

Untuk menganalisa kearifan lokal sebagai jawaban dalam hal ahli waris pengganti, bisa dilihat hasil dari penelitian Tenni Puspanata, di dataran Sumatra Utara yang terletak di Kecamatan Siantar, Antara keluarga Almarhum Ronald Tobing dengan keluarga almarhum Umar Harahap, kedua keluarga Batak ini memiliki keturunan yang berhak mendapatkan warisan atas meninggalnya kedua almarhum diatas. Namun salah satu dari anak mereka yang berhak mendapatkan hak waris ada 
yang telah meninggal, kasus di atas menjadi menarik karena dalam keluarga di atas metode pembagian hak warisnya menggunakan sistem pewarisan yang berbeda.

Sistem kedudukan ahli waris pengganti di dalam hukum kewarisan Islam hanya mengenal pembagian waris bagi yang masih hidup saja akan tetapi di dalam Kompilasi Hukum Islam (KHI) bahwa keberadaan akan cucu diakui dan mendapatkan bagian warisan harta benda dan kekayaan, sebagai pengganti dari orang tuanya yang telah meninggal dunia lebih dahulu dari pewaris. Sedangkan dalam hukum kewarisan adat Batak keberadaan akan ahli waris pengganti itu diakui dan yang berhak menerima warisan hanya cucu laki-laki saja. ${ }^{30}$

Penyelesaian sengketa dalam hal pembagian waris menurut hukum waris adat Batak maupun Islam apabila terjadi permasalahan akan pembagian waris hendaknya diselesaikan secara kekeluargaan. Namun di dalam adat Batak yang menganut sistem patrilineal maka hanya laki-laki yang berhak memperoleh harta pusaka dan harta warisan peninggalan orangtuanya, sedangkan untuk perempuan tidak mendapatkan bagian warisan harta benda dan kekayaan, karena telah diberikan terlebih dahulu sebelum orangtuanya meninggal dunia. Untuk penyelesaian sengketa waris menurut hukum Islam yang memperoleh hak bagian waris adalah ahli waris pengganti, namun besarnya bagian yang diberikan tidak sama persis dengan bagian yang seharusnya diterima ahli waris yang meninggal terlebih dahulu, sehingga bagian yang diberikan kepada ahli waris pengganti ini disebut dengan hibah sebab hasil pemberian dari keluarga.

Sehubungan dengan itu, pembaharuan dan pembentukan hukum kewarisan Islam selain dilakukan oleh pembentuk peraturan perundang-undangan (seperti hukum kewarisan dalam KHI) dapat juga dilakukan oleh hakim melalui ijtihad hakim Peradilan Agama. Ijtihad itu berupa pengembangan hukum Kewarisan dalam KHI untuk memecahkan dan memutus suatu perkara hukum kewarisan Islam yang tidak diatur dalam KHI. Melalui pengadilan, kekuasaan negara di bidang hokum Islam menjelma secara kongkrit. ${ }^{31}$

Dari hal itu, hukum waris Islam dalam Kompilasi Hukum Islam (KHI) tetap dilakukan ijtihad berupa menafsirkan hukum waris Islam dengan mengakomodir hukum Adat seperti cucu dapat menggantikan kedudukan ayahnya dalam mewarisi kakeknya atau neneknya dengan cara memperoleh sebagai "ahli waris pengganti".

Dalam kitab-kitab fikih klasik ketentuan demikian tidak ada, karena warisan itu pada dasarnya hanya untuk ahli waris yang masih hidup. Demikianpun KHI memberi hak kepada anak angkat atau orang tua angkat, sedangkan al-Qur'an jelasjelas tidak mengakui keberadaan anak angkat atau orang tua angkat karenanya tidak mempunyai akibat hukum. Akan tetapi anak angkat atau orang tua angkat mendapat warisan karena melalui konsep "wasiat wajibah".

Hibah dan penyelesaian waris secara damai tampak lebih disenangi masyarakat muslim Indonesia. Kondisi ini sesuai dengan hasil penelitian yang

30 Tenni Puspanata, Status Kedudukan Ahli Waris Pengganti (Plaatsvervulling) Menurut Hukum Adat Batak Dan Hukum Waris Islam, Skripsi, (tidak diterbitkan).

31 Bagir Manan, "Peranan Peradilan Agama dalam Pembinaan Hukum Nasional," di dalam Yuhaya S. Praja, Hukum Islam Indonesia: Pemikiran dan Praktek, Cet. 1, Bandung: Remaja Rosdakarya, 1991, h. 134

ADHKI: Journal of Islamic Family Law 
dilakukan oleh Kamsi dengan subjek masyarakat santri menunjukkan bahwa masyarakat umumnya menggunakan hibah wasiat dengan memberikan harta kepada anaknya selama orang tua masih hidup. Jika harus menggunakan hukum waris mereka membaginya dengan tasalluh (perdamaian), masing-masing ahli waris mengadakan kesepakatan tentang harta peninggalan orang tuanya. Meski tidak menggunakan hukum waris secara tekstual seperti dalam al-Qur'an tindakan mereka dibenarkan oleh syara'. ${ }^{32}$

Dari kasus posisi di atas, dapat dinyatakan bahwa keberadaan hokum kewarisan yang dipandang qath'i itu dapat berubah menjadi dhanny pada tingkat penerapan (aplikasi) melalui putusan Pengadilan Agama. Hal ini wajar karena Pengadilan Agama di samping sebagai "institusi hukum" juga sebagai "institusi sosial". Pengadilan merupakan institusi yang dinamis. ${ }^{33}$

\section{Kebijaksanaan Hakim dalam Memutuskan Perkara Ahli Waris Pengganti}

Sebagai institusi sosial, peran Pengadilan Agama (para hakimnya) harus dapat mengakomodir perkembangan sosial (teori kausalitas, teori nasakh). Hukum waris termasuk hokum mu'amalah, maka dapat dikembangkan (terbuka) sesuai alasannya (teori ajaran non dasar, teori ta'aqquli). ${ }^{34}$ Orientasi penerapan hukum waris adalah keadilan dan pada tingkat penerapan di pengadilan itu yang dihadapi adalah hukum kasus. Dalam hukum kasus yang dihadapi pengadilan, yaitu kasus berbeda-beda dan nuansapun berbeda-beda pula, sehingga putusan berbeda pula (teori illat hukum, teori rasionalitas). Dengan kata lain, bahwa hukum kewarisan yang dipandang qath'i atau ta'abbudi pada tingkat pelaksanaan (tanfidz) bisa dhanny atau ma'qulat al-ma'na untuk mewujudkan keadikan sebagaimana yang dikehendaki oleh Al-Syari'. Dalam dinamika perkembangan itu, hukum Islam mempunyai kaidah asasi yang merupakan sumber hukum Islam yang ke tiga, yaitu: al-ra'yu (pemikiran) dengan metode ijtihad yang dapat menjawab tantangan zaman dan memenuhi harapan dengan tetap memelihara "ruh Islam" dan hukum Islam yang tidak dapat dilepaskan dengan "maqashid alsyari'ah" bahwa Islam dan hukum Islam itu pasti menciptakan "jalbu al-mashalih wa dar'u almafasid" (mendatangkan kebaikan dan menolak keburukan" dan ujungujungnya memberikan keadilan. ${ }^{35}$

Kemaslahatan itu melalui analisis maqashid al-syari'ah tidak hanya dilihat dalam arti teknis belaka, akan tetapi dalam upaya dinamika dan pengembangan hukum dilihat sebagai suatu yang mengandung nilai filosofis dari hukum-hukum yang disyariatkan Allah terhadap manusia. ${ }^{36}$

${ }^{32}$ Kamsi, "Kewarisan Benda Tetap pada Masyarakat Santri: Studi Kasus Desa Maguwoharjo Depok Sleman", dalam Asy-Syir'ah, Vol. 35, No. II, Tahun 2001, h. 122-123

33 Satjipto Rahardjo, "Pengadilan Agama Sebagai Pengadilan Keluarga", dalam Mimbar Hukum No. 10 Thn. IV 1993, h. 23.

${ }^{34}$ Lihat Selengkapnya Abdul Qodir Zaelani, “Konsep Ta'aqquli dan Ta'abbudi dalam Konteks Hukum Keluarga Islam”, Asas, Vol 6, No. 1, 2014, h. 46-56.

${ }^{35}$ A. Khisni, Transformasi Hukum Islam Ke Dalam Hukum Nasional (Studi Ijtihad Hakim Peradilan Agama Tentang Pengembangan Hukum Kewaarisan Dalam Kompilasi Hukum Islam dan Kontribusinya Terhadap Hukum Nasional), Program Doktor Ilmu Hukum UII, Yogyakarta, 2010, h. 439.

${ }^{36}$ Asfari Jaya Bakti, Konsep Maqashid al-Syari'ah menurut Al-Syatibi dan Relevansinya Dengan Ijtihad Hukum Dewasa Ini, Program Pascasarjana IAIN Syarif Hidayatullah, Jakarta, 1994, h. 96 
Kompilasi Hukum Islam (KHI) khususnya bidang hukum kewarisan telah selesai diundangkan (an-nushush mutanahiyah), tetapi kehidupan keluarga muslim dalam bidang hukum keluarga pada umumnya dan khususnya bidang hukum kewarisan tidak pernah selesai (al-waqa'iq ghairu mutanahiyah), berkembang dan dinamis, maka KHI perlu dikembangkan melalui putusan (tahrij al-ahkam 'ala nashil qanun), via Ijtihad hakim Peradilan Agama dalam upaya menjawab perkembangan zaman. Kedua, perlu mengoptimalkan putusan (yurisprudensi) dari Peradilan Agama sebagai wujud pengembangan Kompilasi Hukum Islam (KHI) yang ditransformasikan menjadi hukum nasional, sehingga dapat melahirkan ajaran hukum menurut Islam menjadi sistem hukum nasional yang dapat dinikmati seluruh masyarakat tanpa membedakan agama.

Namun demikian, hakim memiliki kebebasan untuk berkreasi sepanjang tidak ditemukan rujukannya dalam hukum tertulis. Bahkan ketentuan pasal 27 ayat (1) Undang-Undang Nomor 14 tahun 1970, menyatakan bahwa hakim sebagai penegak hukum dan keadilan wajib menggali, mengikuti, dan memahami nilai-nilai hukum yang hidup dalam masyarakat. ${ }^{37}$

\section{Kesimpulan}

Dari pemaparan di atas jelaslah bahwa adanya ahli waris pengganti yang termaktub di dalam KHI merupakan terobosan unik yang tidak ada secara tegas dalam kitab al-Qur'an dan Hadist. Dan ini merupakan pembaharuan dalam masalah hukum keluarga Islam di Indonesia. Eksistensi ahli waris pengganti yang terdapat dalam KHI, mengindikasikan bahwa hubungan hukum Islam dengan adat tidak dapat dilepaskan. Dan asas yang digunakan dalam perumusan ahli waris pengganti mengarah kepada asas maslahat yang menginginkan nilai-nilai keadilan tercipta. Semoga tulisan ini bermanfaat.

\section{Daftar Pustaka}

Hadikusuma, Hilman, Hukum Waris Adat, Bandung: PT. Citra Aditya Bakti, 1990

Subekti, Ringkasan Tentang Hukum Keluarga dan Hukum Waris, Jakarta: Intermasa, 1990

Pitlo, A, Hukum Waris. Menurut Kitab Undang-Undang Hukum Perdata Belanda, Jilid 2, Jakarta: PT Intermasa, 1991

Syarifuddin, Amir, Pelaksanaan Hukum Kewarisan Islam Dalam Lingkungan Adat Minangkabau Jakarta: Gunung Agung, 1984

Sudiyat, Imam, Peta Hukum Waris di Indonesia, Jakarta: Simposium Hukum Waris Nasional, 1983

Ali, Zainuddin, Pelaksanaan Hukum Waris di Indonesia, Jakarta: Sinar Grafika, 2008

Hazairin, Hukum Kewarisan Bilateral Menurut Qur'an dan Hadith, Jakarta: Tintamas, 1964

Ismuha, Penggantian Tempat Dalam Hukum Waris Menurut K.U.H.Perdata, Hukum Adat dan Hukum Islam, Jakarta: Bulan Bintang, 1978

Usman, Suparman, Ikhtisar Hukum Waris Menurut Kitab Undang-Undang Hukum Perdata (Burgerlijk Wetboek), Serang: Darul Ulum Press, 1993

37 Republik Indonesia, “Undang-Undang RI Nomor 14 Tahun 1970 tentang Pokok-Pokok Kekuasaan Kehakiman". 
Abdurrahman, Paradigma Baru tentang Kewenangan Peradilan Agama di Indonesia, h.7. Makalah disampaikan pada seminar dalam rangka Rapat Kerja Para Dekan Fakultas Syariah seluruh Indonesia di Banjarmasin tanggal 19 September 2006

Mu'adz, Farid, dalam pengaruh ajaran "Tsulutsul Baaqi" dalam Kompilasi Hukum Islam, Panji Masyarakat, Nomor 806, 16 Jumadil Awwal 1415 H, 11-21 Oktober 1994

Soejoeti, Zarkowi, "Sejarah Penyusunan Kompilasi Hukum Islam di Indonesia”, dalam Dadan Muttaqien, dkk., Peradilan Agama dan Kompilasi Hukum Islam dalam Tata Hukum Indonesi, edisi II Yogyakarta: UII Press, 1999

Attamimi, A. Hamid S, "Kedudukan Kompilasi Hukum Islam dalam Sistem Hukum Nasional" dalam Amrullah Ahmad dkk., Dimensi Hukum Islam dalam Sistem Hukum Nasional, cet. ke-1; Jakarta: Gema Insani Press, 1996

Herawati, Andi, Kompilasi Hukum Islam (KHI) Sebagai Hasil Ijtihad Ulama Indonesia, Jurnal Studia Islamika, Vol. 8, No.2, Desember 2011

Zahari, Ahmad, Hukum Kewarisan Islam, Pontianak: FH Untan Pres, 2008

Syarifuddin, Amir, Pelaksanaan Hukum Kewarisan Islam dalam Lingkungan Adat Minangkabau, Jakarta: Gunung Agung, 1984

Bakti, Asfari Jaya, Konsep Maqashid al-Syari'ah menurut Al-Syatibi dan Relevansinya dengan Ijtihad Hukum Dewasa Ini, Program Pascasarjana IAIN Syarif Hidayatullah, Jakarta, 1994

Kamsi, "Kewarisan Benda Tetap pada Masyarakat Santri: Studi Kasus Desa Maguwoharjo Depok Sleman", dalam Asy-Syir'ah, Vol. 35, No. II, Tahun 2001

Rahardjo, Satjipto, "Pengadilan Agama Sebagai Pengadilan Keluarga", dalam Mimbar Hukum No. 10 Thn. IV 1993

Khisni, A, Transformasi Hukum Islam Ke Dalam Hukum Nasional (Studi Ijtihad Hakim Peradilan Agama Tentang Pengembangan Hukum Kewaarisan Dalam Kompilasi Hukum Islam dan Kontribusinya Terhadap Hukum Nasional), Program Doktor Ilmu Hukum UII, Yogyakarta, 2010.

Manan, Bagir, "Peranan Peradilan Agama dalam Pembinaan Hukum Nasional," di dalam Yuhaya S. Praja, Hukum Islam Indonesia: Pemikiran dan Praktek, Cet. 1, Bandung: Remaja Rosdakarya, 1991

Puspanata, Tenni, Status Kedudukan Ahli Waris Pengganti (Plaatsvervulling) Menurut Hukum Adat Batak Dan Hukum Waris Islam, Skripsi, (tidak diterbitkan)

Budiono, A. Rachmad, Pembaharuan Hukum Kewarisan Islam di Indonesia, Bandung: PT. Citra Aditya Bakti, 1999

Thalib, Sajuti, Hukum Kewarisan Islam di Indonesia, Jakarta: Bina Aksara, 1982.

Zaelani, Abdul Qodir, “Konsep Ta'aqquli dan Ta'abbudi dalam Konteks Hukum Keluarga Islam”, Asas, Vol 6, No. 1, 2014, h. 46-56 